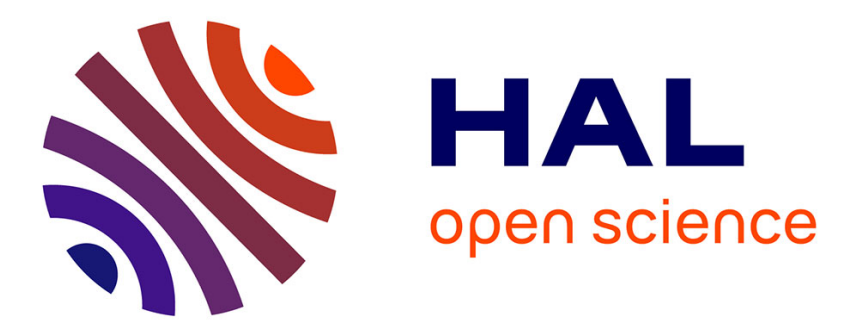

\title{
Seasonal changes in zooplanktonic alkaline phosphatase activity in Toulon Bay (France): the role of Cypris larvae
}

Natacha Jean, Gérard Bogé, Jean-Louis Jamet, Simone Richard, Dominique Jamet

\section{- To cite this version:}

Natacha Jean, Gérard Bogé, Jean-Louis Jamet, Simone Richard, Dominique Jamet. Seasonal changes in zooplanktonic alkaline phosphatase activity in Toulon Bay (France): the role of Cypris larvae. Marine Pollution Bulletin, 2003, 46 (3), pp.346 - 352. 10.1016/S0025-326X(02)00450-2 . hal-01885196

\section{HAL Id: hal-01885196 \\ https://hal.science/hal-01885196}

Submitted on 1 Jun 2021

HAL is a multi-disciplinary open access archive for the deposit and dissemination of scientific research documents, whether they are published or not. The documents may come from teaching and research institutions in France or abroad, or from public or private research centers.
L'archive ouverte pluridisciplinaire HAL, est destinée au dépôt et à la diffusion de documents scientifiques de niveau recherche, publiés ou non, émanant des établissements d'enseignement et de recherche français ou étrangers, des laboratoires publics ou privés. 


\title{
Seasonal changes in zooplanktonic alkaline phosphatase activity in Toulon Bay (France): the role of Cypris larvae
}

\author{
Natacha Jean, Gérard Bogé, Jean-Louis Jamet, Simone Richard, Dominique Jamet * \\ Département de Génie Biologique, Laboratoire des Echanges Particulaires aux Interfaces UPRES EA 1723, \\ Université de Toulon et Var, BP 132, 83957 La Garde cedex, France
}

\begin{abstract}
We studied zooplankton contribution to the total particulate phosphatase activity, the kinetics of this activity, the relation to the different taxonomic groups and the role of particle-bound bacteria. The activity of total particulate material collected from a liter of seawater was more elevated in May, June and August than during the rest of the year. These high activities resulted from a high contribution of the $>90 \mu \mathrm{m}$ fraction which account then for more than $60 \%$ of the total particulate activity. Two Michaelian processes with high and low $V_{\max }$ were disclosed on this fraction. The high $V_{\max }$ component was responsible for the high summer activities. During these periods, high densities of cirriped Cypris were found which were statistically correlated with this high $V_{\text {max }}$ component as with its specific activity. Moreover, the contribution of attached bacteria to these high activities was low. In return, this contribution was predominant during the periods of low activity. A simple method was developed to characterise this bacterial activity.
\end{abstract}

Keywords: Phosphatase activity; Marine zooplankton; Cypris larva; Particle-bound bacteria; Particulate matter; Eutrophication

\section{Introduction}

Orthophosphate $(\mathrm{Pi})$ is generally considered to be directly available to and rapidly assimilated by bacteria and phytoplankton (Currie and Kalff, 1984). As the amount of inorganic phosphorus available is often insufficient to satisfy the requirements of plankton, attention has focused on mechanisms by which Pi can be generated from phosphoric esters. Phosphatases are enzymes that hydrolyze a variety of organic phosphorus compounds into orthophosphate and alcohol. These enzymes are particularly active when dissolved inorganic phosphorus (DIP) concentrations are low (Jansson et al., 1988). They may allow plankton to develop even when there is a lack of DIP (Petterson, 1980; Gage and Gorham, 1985). Thus, the phosphatases considerably increase the amount of phosphorus available. Phytoplankton (Stewart and Wetzel, 1982), bacteria (Halemejko and Chrost, 1984) and zooplankton (Wynne and Gophen, 1981; Boavida et al., 1984) all contain

\footnotetext{
${ }^{*}$ Corresponding author.

E-mail address: d.jamet@univ-tln.fr (D. Jamet).
}

phosphatases. But the part played by these organisms in the production and in the secretion of these enzymes in aquatic ecosystems has not been clearly identified. Several authors have demonstrated that bacteria or phytoplankton are the major sources of the phosphatase activity in these systems, whereas for others the contribution of zooplankton is noticeable (Berman, 1970; Rivkin and Swift, 1979; Chrost et al., 1986; Chrost and Overbeck, 1987; Huang and Hong, 1999).

We have been investigating phosphatase activity in different coastal Mediterranean marine ecosystems in the Toulon area, France, for several years. Toulon Bay is subject to high levels of military and commercial activities which in term disturbs the natural biological equilibrium (Paillard et al., 1993). Consequently, within Toulon Bay high densities of phyto- and zooplankton are associated with a low planktonic biodiversity index. We have shown that zooplankton is an important contributor to the particulate phosphatase activity in Toulon bay and that this activity increases as the density of zooplankton increases. In addition, certain species, such as cirriped Cypris, may be responsible for the high specific activities observed at certain periods of the year (Jamet and Boge, 1998; Gambin et al., 1999; Bogé et al., 
2002). Our aim was to define the precise role of zooplankton in the production of phosphatase during an annual cycle. We particularly studied the kinetics of the activities in relation to the different taxonomic groups and the role of particle-bound bacteria.

\section{Materials and methods}

\subsection{Study sites}

Toulon (central point Lat. $43^{\circ} 05^{\prime} \mathrm{N}$ and Long. $\left.6^{\circ} 00^{\prime} \mathrm{E}\right)$ is on the French N.W. Mediterranean coast (Fig. 1) and has approximately 160000 habitants. Its seaport handles military, commercial and tourist traffic. Surface currents (from west to east and from east to west) are generated by the dominant winds (N.-W. and S.-E.) in the bay. There is also an under-current which runs from N.-W. to S.-E. Toulon Bay is composed of two parts separated by a breakwater: the western basin, the "petite rade" is semi-enclosed and the eastern basin, the "Grande rade", is open to the sea. The "petite rade" contains high level of contaminants, notably PAH, DDT, metals and occasionally toxins (IFREMER, 1993). The sampling stations were located in the "petite rade".

\subsection{Field sampling}

The experiments were carried out between November 1999 and September 2000 between 9.30 and $11.00 \mathrm{am}$. For enzyme activities and protein concentration determinations, seawater was collected in an horizontal Van Dorn bottle at a depth of two meters and used to measure enzyme activity and protein concentration. We filtered in series between 10 and 201 of seawater through filters with 90,5 and $0.25 \mu \mathrm{m}$ pores. Enzyme activity was measured immediately using the particulate material collected on the filters. Protein analysis was carried out using filters kept at $-80^{\circ} \mathrm{C}$.
For zooplankton analysis, recent studies showed the importance of the smaller size fractions (Calbet et al., 2001; Jamet et al., 2001). Thus, zooplankton community was sampled with a $90 \mu \mathrm{m}$ plankton net $(0.5 \mathrm{~m}$ diameter and $2.5 \mathrm{~m}$ length) by vertical tows. The volume of water filtered (5.0-21.4 $\left.\mathrm{m}^{3}\right)$ was measured with a flowmeter. Samples for zooplankton analysis, were immediately stored in buffered $\left(\mathrm{CaCO}_{3}\right)$ seawater containing 5\% formalin.

\subsection{Enzyme activities}

The above described filters (90, 5 and $0.25 \mu \mathrm{m})$ were placed into filtered $(0.25 \mu \mathrm{m})$ seawater. Phosphatase activity was measured at $25{ }^{\circ} \mathrm{C}$ with paranitrophenyl phosphate (p-NPP) as the substrate, by reading absorbance at $410 \mathrm{~nm}$ (Reichardt et al., 1967; Jamet et al., 1995). A range of substrate concentrations (0.01-15 $\mathrm{mM})$ was prepared in filtered $(0.25 \mu \mathrm{m})$ seawater. Blanks were prepared using filtered seawater and used to measure any dissolved enzymes.

The $>90 \mu \mathrm{m}$ activity was measured using the particulate material collected on the $90 \mu \mathrm{m}$ filters. The total activity was given by the sum of the activities collected on the three filters. Activities were expressed as $V_{\max }$ (the reaction rate when the enzyme is saturated with substrate) to limit the effect of orthophosphate ions from seawater or tissue extracts. $V_{\max }$ was calculated by linearizing the Michaelis-Menten equation using the Eadie Hofstee method (activity vs activity/substrate concentration) such that the intercept of the curve and the ordinate gives $V_{\max }$ (Lehninger, 1975). The standard deviation of each $V_{\max }$ was also calculated using the "Curve expert" software (Microsoft Corp).

When the curves were non-linear, a calculation program was used to discriminate the different michaelien components as shown in the Fig. 2. In this example, the total activity is the sum of two Michaelis-Menten processes. The difference between the measured and the theoretical values were less than $6 \%$.

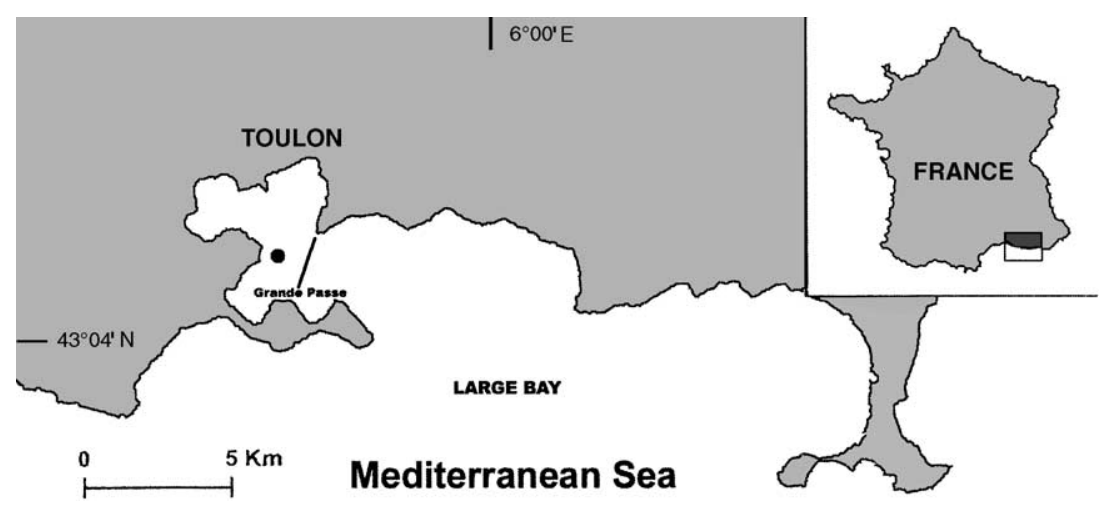

Fig. 1. Map of Toulon area and the sampling station ( 


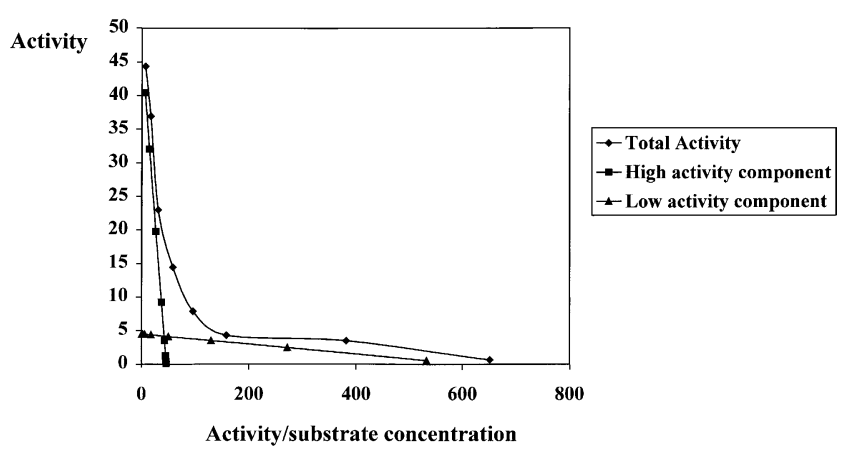

Fig. 2. Analysis of activity according to Eadie Hofstee method.

\subsection{Protein concentration}

Protein concentration was used as a measure of zooplankton biomass. The frozen particulate material was thawed and suspended in distilled water. $\mathrm{NaOH}$ was added to the suspension (final concentration: $0.1 \mathrm{~N}$ ) to dissolve the proteins. The protein concentrations were determined according to the Lowry method (Lowry et al., 1951) using bovine serum albumin as a standard. The absorbance was measured at $660 \mathrm{~nm}$.

\subsection{Zooplankton analysis}

Subsamples of the zooplankton collected with the net, were randomly obtained with a Hensen pipette from the sample adjusted to $250 \mathrm{ml}$. The most abundant species were identified and counted.

\subsection{Statistical analysis}

The correlations between phosphatase activity, plankton abundance, protein concentrations and dry weights were determined using the non-parametric Spearman correlation test.

\section{Results}

\subsection{Analysis of the kinetic components of the phosphatase activity}

The total activities were first adjusted for the volume of the seawater (Fig. 3). The $V_{\max }$ of the total particulate activity and of the $>90 \mu \mathrm{m}$ size fraction varied considerably with the seasons. Thus, phosphatase activity was generally low in winter and at the beginning of spring, and high in summer (except in July). It then decreased again in September. For the $90 \mu \mathrm{m}$ size fraction the minimum was $4.5 \mathrm{nmol1}^{-1}$ in February and the maximum was $204.9 \mathrm{nmoll}^{-1}$ in June (Fig. 3). This fraction accounted for between $15 \%$ and $80 \%$ of the total particulate activity $(>0.25 \mu \mathrm{m})$ depending on the season

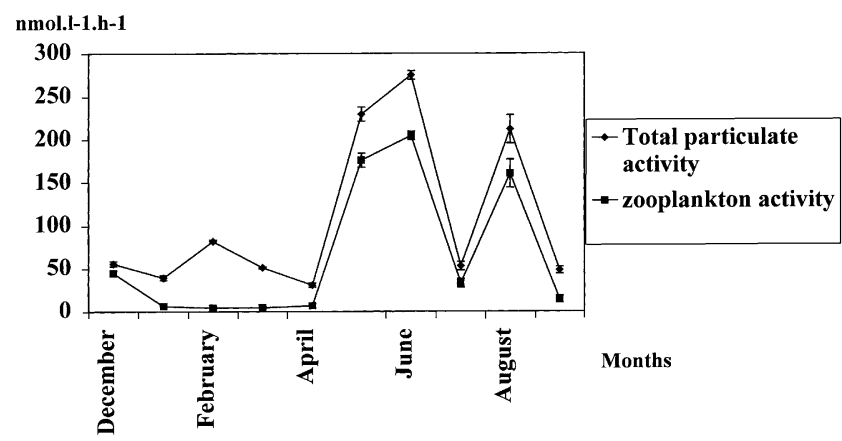

Fig. 3. Seasonal variations of total and zooplankton activities $\left(\mathrm{nmoll} \mathrm{l}^{-1} \mathrm{~h}^{-1}\right)$.

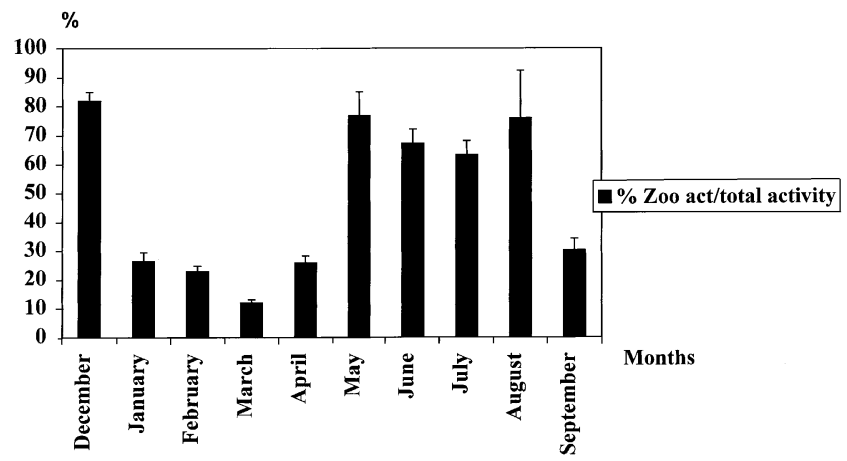

Fig. 4. Seasonal variations of the zooplanktonic activity and the total activity ratio.

(Fig. 4). This contribution was particularly high in December, but especially when the total particulate activity was elevated (May, June and August) with values higher than $60 \%$.

All of the Eadie Hofstee curves were non-linear indicating that at least two Michaelian processes are involved in the hydrolysis of phosphoric esters. The first component of the enzyme activity was characterized by a high $V_{\max }$. This component was the main cause of the high total activity observed in the summer. The second component had a low activity and varied less with the seasons. As for the first component, the highest values of the low activity component were observed in June and August (Fig. 5). The contribution of the high activity component to the total activity increased during the periods when the total particulate or the total $90 \mu \mathrm{m}$ size fraction activity was high (from May to August; Fig. 6).

We also calculated specific activities, taking biomass into account. For this purpose, the activities of the two components, were expressed in relation to protein concentrations. Throughout our study, the total specific

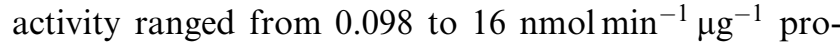
tein. The highest two values (16 and $9.5 \mathrm{nmol} \mathrm{min}^{-1} \mu \mathrm{g}^{-1}$ protein) occurred in June and August respectively (Fig. 7). As shown previously, when the values were adjusted of seawater volumes, these periods of high activity were 


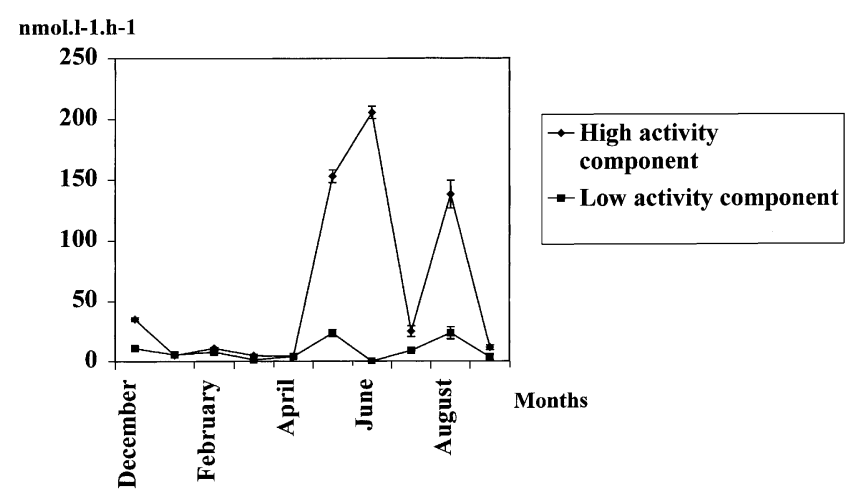

Fig. 5. Seasonal variations of the low and the high activity components $\left(\mathrm{nmol} 1^{-1} \mathrm{~h}^{-1}\right)$.

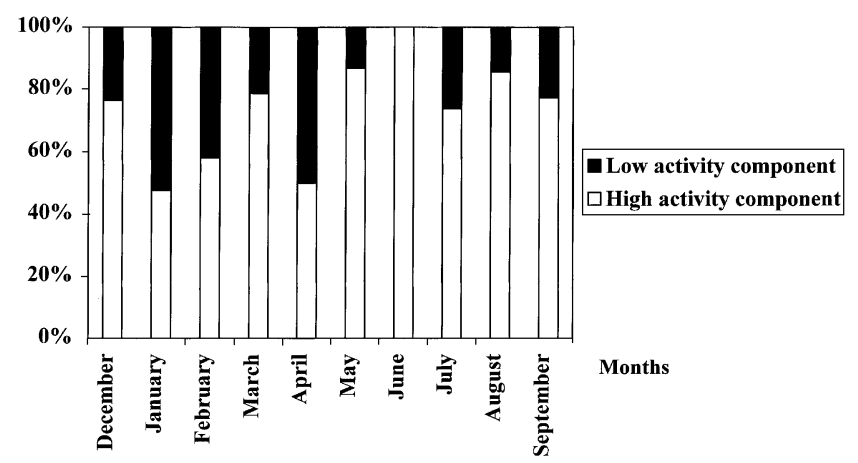

Fig. 6. Relative contribution of the low and the high activity components.

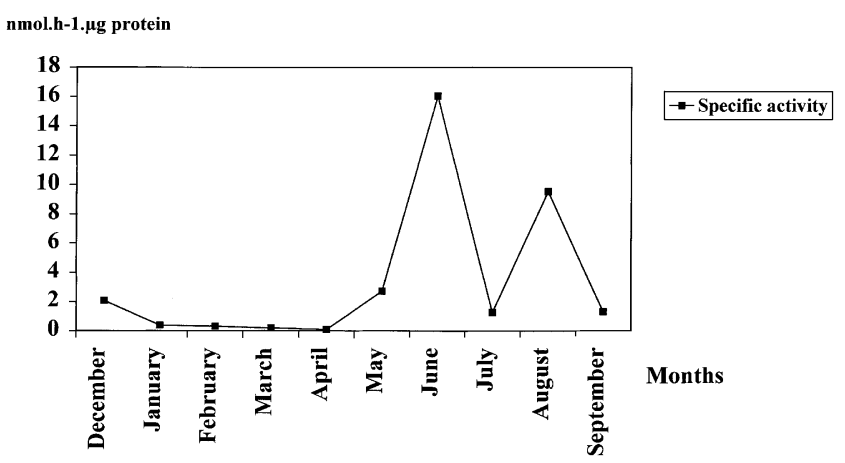

Fig. 7. Seasonal variations of the specific activity $\left(\mathrm{nmoll}^{-1} \mu \mathrm{g}^{-1}\right)$.

due to a greater contribution from the high activity component.

\subsection{Relationship between phosphatase activity and zoo- plankton density}

As we have previously shown (Jamet et al., 2001), the Toulon seaport contains high densities of zooplankton, the abundance of which varies with the seasons. The total phosphatase activity and the density of zooplankton seemed to vary in parallel. But no significant correlation $(p>0.05)$ was found between enzyme activity and the total density of zooplankton, whereas strong correlation $(p=0.002)$ was found between enzyme activity and the density of cirripeds cypris (Fig. 8). We also found a strong correlation $(p=0.001)$ between the percentage of zooplanktonic activity and cypris densities. The number of cypris was particularly high in June and August, which corresponds to a period of high phosphatase activity. This correlation was due solely to the high activity component $(p=0.05)$. Moreover, these larvae seemed to account for the high specific activities observed in summer for the total activity of the $>90 \mu \mathrm{m}$ fraction and its high activity component $(p=0.05)$.

\subsection{Relationship between phosphatase activity and bac- terial abundance}

To determine whether particle-bound bacteria were involved in the phosphatase activity of the material collected on the $>90 \mu \mathrm{m}$ filters, we monitored the hydrolysis of $\mathrm{p}$-NPP over $24 \mathrm{~h}$ periods in the presence of a high p-NPP concentration $\left(15 \mathrm{mmoll}^{-1}\right)$. In these conditions, an increase in activity with time was observed. This phenomenon was related to the presence of enzyme producing bacteria. This can be demonstrated using the particulate material collected on filters of between 0.25 and $5 \mu \mathrm{m}$ in size. This material contains high proportions of bacteria, whereas the $>90 \mu \mathrm{m}$ in size material contains above all zooplankton. The Fig. 9 showed that the increase in the enzyme activity was particularly high for this $0.25-5 \mu \mathrm{m}$ fraction.

To quantify this increase, the ratio between the activity measured after $24 \mathrm{~h}$ and the beginning of the assay $\left(T_{0}\right)$ was calculated for the two size class fractions ( $R$ values). Higher values were found for the $0.25-5 \mu \mathrm{m}$ fraction and confirmed the relation of $R$ to the bacteria density. This ratio was then studied as a function of the substrate concentration (Fig. 10). In such conditions, $R$ values increased with p-NPP concentration up to $2 \mathrm{mM}$ and were stabilised for higher concentrations. Moreover, they were always lower for the $>90$ size class than those of the $0.25-5 \mu \mathrm{m}$ size class. Such results suggest that $\mathrm{p}-\mathrm{NPP}$, or the products of its hydrolysis $(\mathrm{Pi})$, promote the growth of bacteria which were initially present on the filters. Consequently, $R$ values can be taken as a quantitative indication of an attached bacterial activity.

Important seasonal changes in the $R$ values were found for the two fractions. For the $>90 \mu \mathrm{m}$ size class, the $R$ value never exceeded 2 and was highest in January, February, March, April and September (Fig. 11). Thus, during these periods, particle-bound bacteria accounted for a significant part of the activity of the $>90 \mu \mathrm{m}$ 


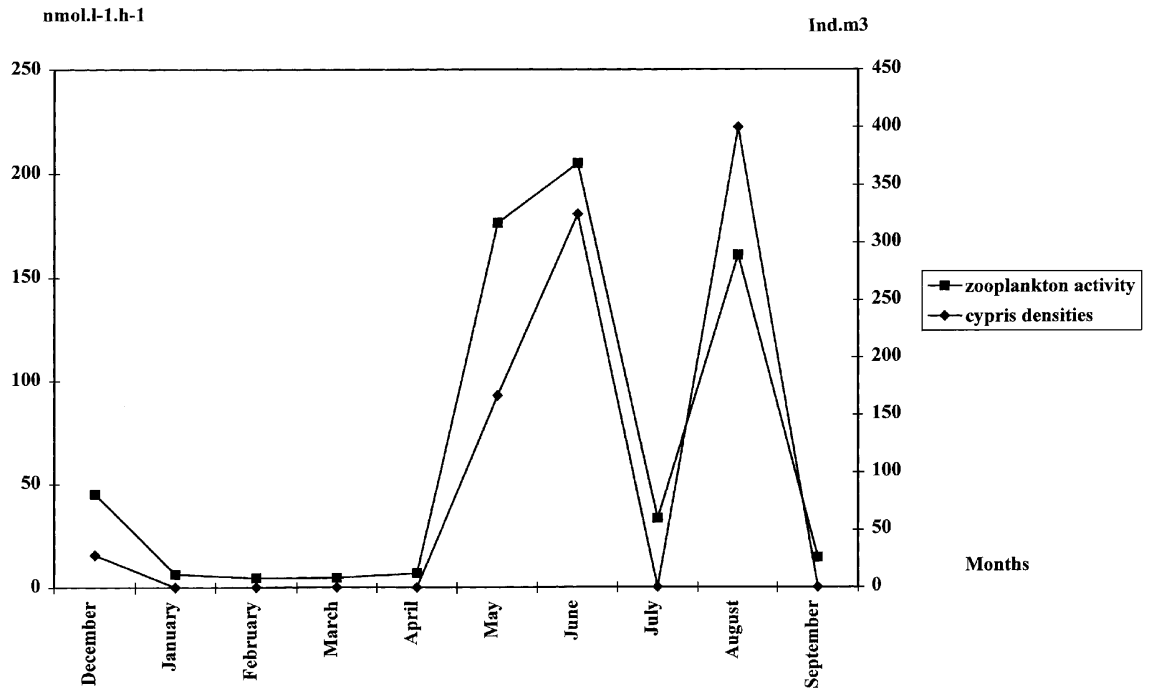

Fig. 8. Seasonal variations of zooplankton activity in relation with cypris densities.

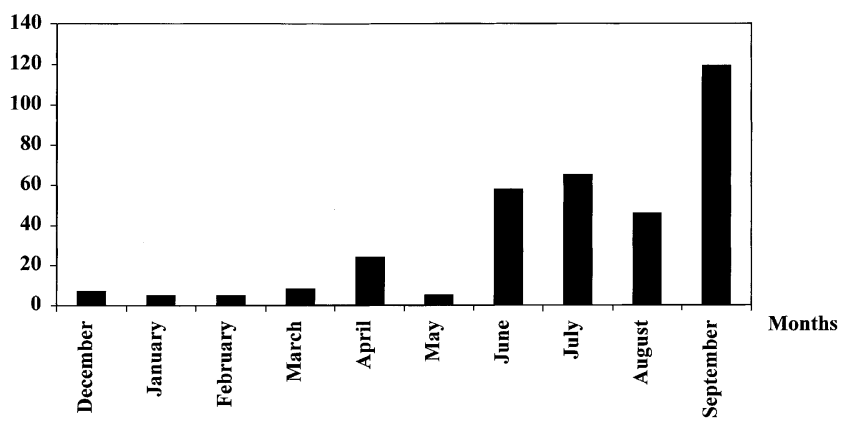

Fig. 9. Seasonal variations of $\mathrm{p}$-NPP hydrolysis $(R$ calculated with $0.25-5 \mu \mathrm{m}$ size fraction).

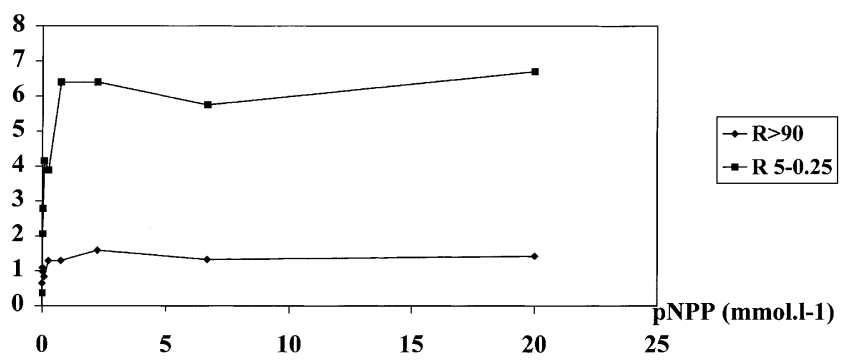

Fig. 10. Evolution of $R$ calculated for the two size classes in relation with p-NPP concentrations.

fraction. If we compare the seasonal variations of this ratio with those of the high activity component of this fraction, it can be seen that the highest $R$ values occurred when the enzyme activity was low and vice versa. This means that bacteria account for a minor part when enzyme activity was high. For the $0.25-5 \mu \mathrm{m}$ fraction the $R$ values increased up to 120 -fold between January and September (Fig. 9).

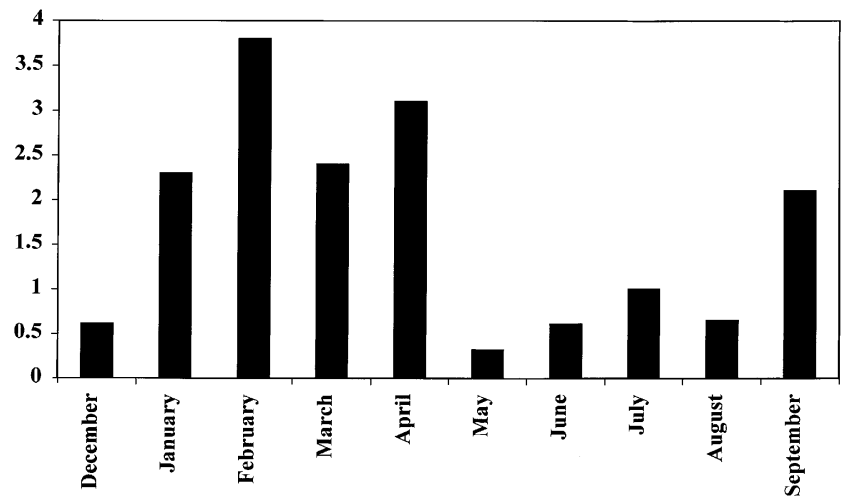

Fig. 11. Seasonal variations of p-NPP hydrolysis $(R$ calculated with $>90 \mu \mathrm{m}$ size fraction).

\section{Discussion}

This study confirms that a specific group of zooplankton (Cypris larvae) accounts for a significant proportion of the total particulate phosphatase activity in Toulon bay (Bogé et al.). Conversely, several authors demonstrated that the major particulate activity is supported by bacteria or phytoplankton (Olsson, 1990; Giraudet et al., 1988; Chrost et al., 1986; Berman, 1970; Stewart and Wetzel, 1982). These differences may be related to the fact that our experiments were carried out in seawater to mimic natural conditions as closely as possible. The $\mathrm{pH}$ of seawater is far from the optimal $\mathrm{pH}$ for phosphatase activity, which is alkaline in the case of alkaline phosphatase or slightly acidic in the case of acid phosphatases. We previously observed that an increase in $\mathrm{pH}$ changes the contribution to alkaline phosphatase activity, and stimulate the activity 
of bacteria and phytoplankton whilst inhibiting the activity of zooplankton (Gambin et al., 1999). In these conditions, several enzymes could be responsible for this total activity, such as alkaline acid phosphatases, or nucleotidases (Ammerman and Azam, 1985).

The total phosphatase activity consisted of a high activity component and a low activity component. Although, we did not analyse the $K_{\mathrm{m}}$ due to the possible effect of phosphorus (a competitive inhibitor of phosphatases), the Eadie Hofstee curves indicated that the low activity component had a higher affinity for the substrate (mean $K_{\mathrm{m}}: 0.062 \mathrm{mM}$ ) than the high activity component (mean $K_{\mathrm{m}}: 2.2 \mathrm{mM}$ ).

In the presence of saturating concentrations of the substrate, the high activity (low affinity) component varied considerably with the seasons. The most significant correlations were found with plankton and cirripeds densities. These observations confirmed that the highest specific activities were due to the presence of these larvae (Bogé et al., 2002). Toulon bay is characterized by high zooplankton densities and a low diversity index. Sixteen taxonomic groups of zooplankton have been recorded in Toulon bay (Jamet and FerecCorbel, 1996) among which copepods were the most abundant group. The dominant species was Oithona nana throughout the entire study period (Jamet et al., 2001) but the highest enzyme activities were associated with the presence of Cypris (cirripeds) at the end of the spring and in the summer. Cirripeds are common on the Mediterranean coast. The cypris stage occurs between the naupliar instar stage and the appearance of sessile adults (Anderson, 1994). Our results show that these larvae make an important contribution to the activity of the low affinity component.

The low activity/high affinity component probably plays an important role in natural conditions due to the low concentrations of organic phosphorus. Unfortunately, the relationship between this component and the densities of zooplankton or cirripeds is less clear than between the high activity component and these densities. Indeed, no significant correlations were found between the low activity component and total zooplankton or the major taxonomic groups. Minor groups may be also responsible for this activity, as for the high activity component.

When the zooplankton and cirriped densities were low, enzyme activities were also low. In such conditions, our results showed that part of this activity was supported by particle-bound bacteria. The role played by attached bacteria was established following the increase in enzyme activity after $24 \mathrm{~h}$ incubations with p-NPP. This increase may result from the utilisation of $\mathrm{p}$-NPP or products of its hydrolysis by bacteria for their growth. This has been attested on the $0.25-5 \mu \mathrm{m}$ fraction which contained high bacteria densities. The activity of this size class over $24 \mathrm{~h}$ increased to a greater extent, especially from June which suggests that bacteria used p-NPP more efficiently during this part of the year. In the case of the $>90 \mu \mathrm{m}$ fraction, the increase of the activity within $24 \mathrm{~h}$ was generally less marked, but it was observed all year round. Moreover, this increase (the $R$ ratio) was greater when activities and cirriped densities were low. In this case, a large part of enzyme activity was supported by bacteria. In contrast, when we observed high cirriped densities, the $R$ ratio were always low. These results confirm that the high activities observed in summer were not due to attached bacteria but to specific organisms such as Cypris.

Bacteria-crustacean interactions are important in the "microbial loop" and biogeochemical cycles in general, especially in polluted areas with increased bacteria densities (Carman and Dodds, 1997). Epibiotic bacteria associated with crustaceans are metabolically quite active (Anderson and Stephens, 1969; Carman, 1989, 1990). They have also enhanced activities (De Angelis et al., 1991). The contribution of attached bacteria to overall bacteria production is highly variable. It is generally accepted that in estuarine and oceanic water column, most bacteria are unattached, free individual cells suspended in the water. A small fraction is attached to particles but rarely to living phytoplankton or zooplankton. However Carman (1994) showed that epibiotic bacteria living on the copepod Labidophora sp. account for approximately $20 \%$ of the total bacterial activity in the polluted Gulf of Mexico. These bacteria may have been ingested by zooplankton. In Toulon seaport, the copepod $O$. nana accounted for $80 \%$ of all zooplankton. This species is known to be omnivorous and to feed on bacteria and phytoplankton (Lampitt and Gamble, 1982). The part played by ingested bacteria in zooplankton activity has been extensively discussed. The characterization of phosphatases excreted by zooplankton using gel filtration (Jansson, 1976), gel electrophoresis (Wynne and Gophen, 1981) and anion exchange chromatography (Boavida and Heath, 1984) indicated that the enzymes released from zooplankton were indeed produced by the animals themselves and not by components of their food. Bacteria associated with the external surfaces of zooplankton might also produce phosphatases. However, no correlation was found between $R$ values and bacterial density.

In conclusion, this work confirms that the highest phosphatase activities are associated with the presence of cyprid in Toulon Bay. These results showed the importance of our choice in zooplankton sampling. It shows that a high activity component, probably with low $K_{\mathrm{m}}$, is responsible for this relationship and that part of this activity is due to bacteria, especially when enzyme activity was low. 


\section{References}

Ammerman, J.W., Azam, F., 1985. Bacterial 5'nucleotidase in aquatic ecosystems: a novel mechanism of phosphorus regeneration. Science 227, 1338-1340.

Anderson, D., 1994. Barnacles: Structure, Function, Development and Evolution. Chapman and Hall, London.

Anderson, J.W., Stephens, G.C., 1969. Uptake of organic material by aquatic invertebrates. VI. Role of epiflora in apparent uptake of glycine by marine crustaceans. Mar. Biol. 4, 243-249.

Berman, T., 1970. Alkaline phosphatase and phosphorus availability in Lake Kinneret. Limnol. Oceanogr. 24, 541-547.

Boavida, M.J., Heath, R.T., 1984. Are the phosphatases released by Daphnia magna components of its food? Limnol. Oceanogr. 29 (3), 641-645.

Boavida, M.J., Spujii, J., Markowitz, D., Heath, R.T., 1984. Are soluble alkaline phosphatases secreted by zooplankton? Ohio J. Sci. $84,77$.

Bogé, G., Jamet, J.L., Richard, S., Jamet, D., Jean, N., 2002. Contribution of copepods, cladocerans and cirripeds to phosphatase activity in Mediterranean zooplankton. Hydrobiologia 468, $147-154$.

Calbet, A., Garrido, S., Saiz, E., Alcaraz, M., Duarte, C.M., 2001. Annual zooplankton succession in coastal NW Mediterranean waters: the importance of the smaller size fractions. J. Plankton Res. 23 (3), 319-331.

Carman, K.R., 1989. Radioactive tracers as a tool for the study of in situ Meiofaunal-microbial trophic interactions in marine sediments. Ph.D. dissertation, Florida State University.

Carman, K.R., 1990. Mechanisms of uptake of radioactive labels by meiobenthic copepods during grazing experiments. Mar. Ecol. Prog. Ser. 68, 71-83.

Carman, K.R., 1994. Stimulation of marine free-living and epibiotic bacterial activity by copepods excretions. FEMS Microbial. Ecol. 14, 255-262.

Carman, K.R., Dodds, F.C., 1997. Epibiotic microorganisms on copepods and other marine crustaceans. Microsc. Res. Techniq. 37, $116-135$.

Chrost, R.J., Overbeck, J., 1987. Kinetics of alkaline phosphatase activity and phosphorus availability for phytoplankton and bacterioplankton in Lake plubsee (North German eutrophic lake). Microbiol. Ecol. 13, 229-248.

Chrost, R.J., Wcislo, R., Halemejko, G.Z., 1986. Enzymatic decomposition of organic matter by bacteria in an eutrophic lake. Arch. Hydrobiol. 107, 145-165.

Currie, D.J., Kalff, J., 1984. A comparison of the abilities of freshwater algae and bacteria to acquire and retain phosphorus. Limnol. Oceanogr. 29, 298-310.

De Angelis, M.A., Reysenbach, A., Baross, J.A., 1991. Surfaces of hydrothermal vent invertebrates: sites of elevated microbial $\mathrm{CH}_{4}$ oxidation activity. Limnol. Oceanogr. 36, 570-577.

Gage, M.A., Gorham, E.G., 1985. Alkaline phosphatase activity and cellular phosphorus as an index of the phosphorus status of phytoplankton in Minnesota lakes. Freshwater Biol. 15, 227.

Gambin, F., Bogé, G., Jamet, D., 1999. Alkaline phosphatase in a littoral Mediterranean marine ecosystem: role of the main plankton size classes. Mar. Environ. Res. 47, 441-456.

Giraudet, H., Abrial, D., Berthon, J., Buisson, B., 1988. Variations nycthémérales de l'activité phosphatase alcaline d'une diatomée Synedra capitata et de deux cyanobactéries: Microcystis aeruginosa et Aphanizomenon flos aquae. Ann. Limnol. 34, 367 (in French).
Halemejko, G.Z., Chrost, R.J., 1984. The role of phosphatases in phosphorus mineralization during decomposition of lake phytoplankton blooms. Arch. Hydrobiol. 101 (4), 489-502.

Huang, B., Hong, H., 1999. Alkaline phosphatase activity and utilization of dissolved organic phosphorus by algae in subtropical coastal waters. Mar. Pollut. Bull. 39, 205-211.

IFREMER, 1993. Qualité du milieu marin littoral. IFREMER et Ministère de l'enseignement supérieur et de la recherche, Ministère de l'agriculture et de la pêche, Ministère de l'é quipement, des transports et du tourisme, Ministère de l'environnement, p. 241.

Jamet, D., Bogé, G., 1998. Characterisation of marine zooplankton alkaline phosphatase in relation to water quality. Hydrobiologia 373/374, 311-316.

Jamet, J.L., Ferec-Corbel, A.S., 1996. Seasonal variations of the zooplankton community in a littoral marine ecosystem: Toulon bay (Var, France). Mar. Life 6 (1/2), 3-8.

Jamet, D., Aleya, L., Dévaux, J., 1995. Diel changes in the alkaline phosphatase activity of bacteria and phytoplankton in the hypereutrophic Villerest Reservoir (Roanne, France). Hydrobiologia 300/301, 49-56.

Jamet, J.L., Bogé, G., Richard, S., Geneys, C., Jamet, D., 2001. The zooplankton community in bays of Toulon area (north-west Mediterranean Sea, France). Hydrobiologia 457 (1/3), 155165.

Jansson, M., 1976. Phosphatases in lake water: characterization of enzymes from phytoplankton and zooplankton by gel filtration. Science 194, 320-321.

Jansson, M., Olsson, H., Petterson, K., 1988. Phosphatases: characteristics and function in lakes. Hydrobiologia 170, 157-175.

Lampitt, R.S., Gamble, J.C., 1982. Diet and respiration of the small planktonic marine copepod Oithona nana. Mar. Biol. 66, 185190.

Lehninger, A.H., 1975. Biochemistry, the molecular basis of cell structure and function. Worth Publishers, New York.

Lowry, O.H., Rosebrough, N.J., Farr, A.L., Randall, R.J., 1951. Protein measurement with the folin phenol reagent. J. Biol. Chem. 193, 265-275.

Olsson, H., 1990. Phosphatase activity in relation to phytoplankton composition and $\mathrm{pH}$ in Swedish lakes. Freshwater Biol. 23, 353362.

Paillard, M., Gravez, V., Clabaut, P., Walker, P., Blanc, J.J., Boudouresque, C.F., Belsher, T., Urscheler, F., Poydenot, F., Sinnassamy, J.M., Augris, C., Peyronnet, J.P., Kessler, M., Augustin, J.M., Le Drezen, E., Prudhomme, C., Raillard, J.M., Pergent, G., Hoareau, A., Charbonnel, E., 1993. Cartographie de l'herbier de Posidonie et des fonds marins environnants de Toulon à Hyères (Var-France). Reconnaissance par sonar latéral et photographie aérienne. Notice de présentation. IFREMER \& GIS POSIDONIE Publ., Fr: 1-36 + 3 cartes annexes.

Petterson, K., 1980. Alkaline phosphatase activity and algal surplus phosphorus as phosphorus deficiency indicator in Lake Erken. Arch. Hydrobiol. 89, 54.

Reichardt, W.J., Overbeck, J., Steubing, L., 1967. Free dissolved enzymes in lake waters. Nature 216, 1345-1347.

Rivkin, R.B., Swift, E., 1979. Diel and vertical patterns of alkaline phosphatase and organic phosphorus utilization in the oceanic dinoflagellate Pyrocystis noctiluca. Mar. Bot. 61, 1-8.

Stewart, A.J., Wetzel, R.G., 1982. Phytoplankton contribution to alkaline phosphatase activity. Arch. Hydrobiol. 93 (3), 265.

Wynne, D., Gophen, M., 1981. Phosphatase activity in freshwater zooplankton. Oikos 37, 369-376. 